\title{
The improvement of planting index paddy through empowerment of water management institution: case study in Leumbah Seulawah District, Aceh Besar
}

\author{
Rini Andriani", Ahmad Adriani, Husaini, Eka Fitria, and Cut Hilda Rahmi \\ Assessment Institute for Agricultural Technology of Aceh Province
}

\begin{abstract}
This paper described the institutional empowerment of water management to increasing cropping index (IP) in Aceh Province. The problem in the empowerment of farmer institutions is the low performance of farmers groups due to the low role of administrators, unclear group members, incomplete and malfunction organizational structure, low farming productivity, and lack of guidance from extension agents. The research was conducted in Lamkubu and Teladan village, Lembah Seulawah sub district, Aceh Besar in August 2019. The respondents who became the research sample were 33 respondents. The variables observed included farmer institutions that support IP increases in Lembah Seulawah District, Aceh Besar. The data collected was tabulated and analyzed descriptively. The result are: has four institutions that are used as an assessment for a farmer group in increasing IP, 1) general institutional performance, the process on farming on the organization is carried out based on of mutual agreement, 2) internal institutional motivation and participation, management has high motivation in running the organization and actively participates $(>50 \%)$ in the procurement of meetings, 3 ) institutional rules, there is no enforcement of sanctions because the rules are determined by deliberation and enforced with discipline, 4) interaction with stakeholder, carried out intensely 1-7 times in one growing season, the assistance provided is appropriate but only some have not been able to use it.
\end{abstract}

\section{Introduction}

The important things to develop agricultural sector was farmer institutions [1]. A farmer group is a farmer institutions which formed to organize farmers in farming directly [2]. The farmer group as a forum for organization and cooperation between members has a very important role in farming life, because all activities and problems were carried out by the group simultaneously [3]. The effort of empowerment by developing members ability in farming through creates a group, network and training. Training was a skill to develop the ability and followed by farmers to support their businesses [4], and location as one of the success factor [5]. The community empowerment is a process and an effort to increase the

* Corresponding author: riniandriani.bptp@gmail.com 
ability and strength of a powerless community to be able to solved the problems by optimizing their resources and potentials [6]. According to Rizal [7], the gathering in partnership made by the government could be effective because it could be accommodate the aspirations of farmer groups [8].

The institutions in agricultural development sector was often experience challenges and problems. To overcome these problems is by increasing institutional capacity [9]. The institutions farmer capacity could be increasing through counseling and mentoring intensively from related agencies [10]. Farmer groups are expected to actively participate in the training so the village government could be evaluated the empowerment of farmer groups in agriculture [11]. The training which given to farmers needs to be evaluated to see the effectiveness of the subject [12]. There are some basic principles of society: not distinguishing between abilities, experience, social position, justice, and social institutions [13].

The farmer institutions are very important so they need to be strengthened to expand the economic access [14]. The stakeholders are farmers as shareholders as well as worker [15]. One of the important factor in developing farmer business was institution capacity [16]. Eskarya and Elihami [17] said, the low coordination function between one institution to other was a fact as low performance of the institutions itself [18]. The government is currently trying to achieve food self-sufficiency in every region. The strategies were carried out by improving agricultural infrastructure and facilities, especially for rice [19]. The fields are require a lot of water and in line with the government's efforts, it is necessary to organize the water system to support farming more effectively [20]. To overcome water shortages, it is necessary to guarantee the availability of water by providing irrigation water during these conditions [21]. The factor of the availability of irrigation infrastructure and farmer group institutions makes the cropping index increase along with the growth of agricultural mechanization in the form of agricultural tools and machinery (alsintan) [22]. Along with the increasing amount of alsintan assistance to farmers in Aceh Province like water pumps, training was also conducted to increase the capacity of farmers and extension workers.

Aceh Besar District has dry land of around 108,980 hectares which is very potential to be irrigated, and it is one of the rice production centers in Aceh Province with a raw area of rice fields of 31,845 ha and an average productivity of 6.16 tons / ha [23]. Data and information on water resources in an area can be used as a basis for determining the appropriate water management technology so as to ensure the sustainability of the availability of water resources [24]. In order to expand the spread of technological innovation provided to the two types of land, a strategic location that is easy to access for local farmers and training was carried out for farmers outside of farmer cooperators [25].

One of the problems faced is the low performance of farmer groups caused by the low role of the management, unclear group members, incomplete and non-functioning organizational structure, low productivity of farming and lack of guidance from extension officers. In addition, the establishment of this institution is not carried out in a participative manner so that it could not accommodate the potential and interests of farmers, which should be the capital for collective action [26]. Even farmer groups are often formed on a temporary basis and are only active at certain times, such as when aid is distributed. Based on the problems, this study aims to describe the institutional empowerment of farmers as an effort to increase the cropping index (IP) in Lembah Seulawah District, Aceh Province.

\section{Material and methods}




\subsection{Research site and methods}

The research was conducted in Lamkubu village and Teladan village, Lembah Seulawah sub district, Aceh Besar district in August 2019. The first stage carried out was coordination with related agencies and local village officials to collect farmers and retrieve the data needed so that the research runs according to the objectives and expected outputs. Then, a farmer survey was carried out which explored information about cropping index (IP) activities carried out at the location of the activity.

\subsection{Determining the location and sample of the study}

Determining the location of the research was carried out through coordination with related agencies with the consideration that Leumbah Seulawah Subdistrict is a food crop production center that has rainfed and dry land types. Lamkubu and Teladan Villages were chosen with the aim of facilitating intensive implementation, management and supervision of activities for the success of cropping index (IP) activities. The respondents who became the research sample were 33 respondents. The research object is farmers who support the increase in the cropping index of food crops in Lembah Seulawah District, Aceh Besar.

\subsection{Observed variables}

The variables observed included farmer institutions that support IP increases in Lembah Seulawah District, Aceh Besar

\subsection{Data analysis}

The data used is quantitative from primary and secondary data. Primary data obtained from questionnaire interviews. Secondary data from literature study. The data tabulated and analyzed descriptively.

\section{Result and discussion}

\subsection{Diversity of water management institutions}

The water management institutions undertaken by farmer groups (poktan) were seen from the process and performance of the organizational management, supporting facilities and infrastructure, efficient use of funds and cooperation with the government. The general organizational performance percentage can be seen in Table 1.

Table 1. Percentage of General Performance of Water Management Institutions in Lembah Seulawah Sub District, Aceh Besar District in 2019

\begin{tabular}{|l|c|c|c|c|}
\hline \multirow{2}{*}{ No } & General Performance & Criteria & $\begin{array}{c}\text { Total } \\
\text { (people) }\end{array}$ & $\begin{array}{c}\text { Percentation } \\
(\mathbf{\%})\end{array}$ \\
\hline \multirow{4}{*}{ A. } & \multirow{4}{*}{ Organisation forming process } & 1. Very low & 0 & - \\
\cline { 3 - 5 } & & 2. Low & 6 & 18 \\
\cline { 3 - 5 } & & 3. Medium & 18 & 55 \\
\cline { 3 - 5 } & & 4. High & 9 & 27 \\
\cline { 3 - 5 } & & 5. Very high & 0 & - \\
\hline \multirow{3}{*}{ B. } & \multirow{3}{*}{ Activity achievement last year } & 1. Very low & 0 & - \\
\cline { 3 - 5 } & & 2. Low & 6 & 18 \\
\cline { 3 - 5 } & & 3. Medium & 27 & 82 \\
\hline
\end{tabular}




\begin{tabular}{|c|c|c|c|c|}
\hline No & General Performance & Criteria & $\begin{array}{c}\text { Total } \\
\text { (people) }\end{array}$ & $\begin{array}{c}\text { Percentation } \\
(\%)\end{array}$ \\
\hline & & 4. High & 0 & - \\
\hline & & 5. Very high & 0 & - \\
\hline \multirow{5}{*}{ C. } & \multirow{5}{*}{$\begin{array}{l}\text { Performance of water } \\
\text { management institutional }\end{array}$} & 1. Very low & 3 & 9 \\
\hline & & 2. Low & 0 & - \\
\hline & & 3. Medium & 18 & 55 \\
\hline & & 4. High & 9 & 27 \\
\hline & & 5. Very high & 0 & - \\
\hline \multirow{5}{*}{ D. } & \multirow{5}{*}{$\begin{array}{l}\text { The existence of facilities } \\
\text { and infrastructure }\end{array}$} & 1. Very low & 7 & 21 \\
\hline & & 2. Low & 7 & 21 \\
\hline & & 3. Medium & 15 & 45 \\
\hline & & 4. High & 4 & 12 \\
\hline & & 5. Very high & 0 & - \\
\hline \multirow{5}{*}{ E. } & \multirow{5}{*}{ Obey the administration } & 1. Very low & 5 & 15 \\
\hline & & 2. Low & 21 & 64 \\
\hline & & 3. Medium & 7 & 21 \\
\hline & & 4. High & 0 & - \\
\hline & & 5. Very high & 0 & - \\
\hline \multirow{5}{*}{ F. } & \multirow{5}{*}{$\begin{array}{l}\text { Monitoring and evaluating in } \\
\text { organisation }\end{array}$} & 1. Very low & 0 & - \\
\hline & & 2. Low & 6 & 18 \\
\hline & & 3. Medium & 27 & 82 \\
\hline & & 4. High & 0 & - \\
\hline & & 5. Very high & 0 & - \\
\hline \multirow{5}{*}{ G. } & \multirow{5}{*}{ The efficiency of fund using } & 1. Very low & 4 & 12 \\
\hline & & 2. Low & 8 & 24 \\
\hline & & 3. Medium & 21 & 64 \\
\hline & & 4. High & 0 & - \\
\hline & & 5. Very high & 0 & - \\
\hline \multirow{5}{*}{ H. } & \multirow{5}{*}{$\begin{array}{l}\text { The successful of institutional } \\
\text { in managing government fund }\end{array}$} & 1. Very low & 4 & 12 \\
\hline & & 2. Low & 7 & 21 \\
\hline & & 3. Medium & 18 & 55 \\
\hline & & 4. High & 4 & 12 \\
\hline & & 5. Very high & 0 & - \\
\hline \multirow{5}{*}{ I. } & \multirow{5}{*}{ Government involvment } & 1. Very low & 0 & - \\
\hline & & 2. Low & 15 & 45 \\
\hline & & 3. Medium & 18 & 55 \\
\hline & & 4. High & 0 & - \\
\hline & & 5. Very high & 0 & - \\
\hline
\end{tabular}

Sources : Main data (2019)

The process of forming an organization begins with a mature process and decisions were taken in a participatory manner. The results of the data obtained, this process is at the highest value in the medium criteria, it means that the farmer groups accept the condition of the process of forming this water management institutional organization is based on mutual consensus. At the end of each year, the organization certainly needs to evaluate the performance of its management. The data shows that all targets are achieved satisfactorily and measured well. All administrators carry out their duties as directed and responsibly. In terms of organizational assets, some poktan already have complete and functioning assets and some other poktan do not have complete assets so that the performance of water management is slightly hampered. Another obstacle is the low administrative order, which is still being done by staff who do not have sufficient skills, and the administrative arrangement has not been carried out completely and neatly. The implementation of monitoring and evaluation has been sufficient to do it regularly, periodically, completely and openly. The 
efficient use of funds is also carried out according to the program and can be accounted for properly. Government assistance in the form of technology can be managed and its use is growing. This institutional organization has a good relationship with the government / related agencies, each organization is involved in planning, implementing and supervising agricultural development, both at the regional and central level.

Adequate facilities and infrastructure are one of the success factors for poktan in running the organization, but another internal factors like the management itself also need to be evaluated to find out whether there are any obstacles that hinder the running of the organization. The percentage of motivation and internal partitioning of water management institutions in Lembah Seulawah District can be seen in Table 2.

Table 2. Percentage of Motivation and Internal Participation of Water Management Institutions in Lembah Seulawah Sub District, Aceh Besar District in 2019

\begin{tabular}{|c|c|c|c|c|}
\hline No & $\begin{array}{c}\text { Motivation and internal } \\
\text { participation }\end{array}$ & Criteria & Total (people) & $\%$ \\
\hline \multirow{5}{*}{ A. } & \multirow{5}{*}{$\begin{array}{c}\text { Management motivation and } \\
\text { awareness }\end{array}$} & 1. Very low & 0 & - \\
\hline & & 2. Low & 0 & - \\
\hline & & 3. Medium & 15 & 45 \\
\hline & & 4. High & 18 & 55 \\
\hline & & 5. Very high & 0 & - \\
\hline \multirow{5}{*}{ B. } & \multirow{5}{*}{ Members interest and motivation } & 1. Very low & 0 & - \\
\hline & & 2. Low & 4 & 12 \\
\hline & & 3. Medium & 25 & 76 \\
\hline & & 4. High & 4 & 12 \\
\hline & & 5. Very high & 0 & 0 \\
\hline \multirow{5}{*}{ C. } & \multirow{5}{*}{ Management participation } & 1. Very low & 0 & - \\
\hline & & 2. Low & 0 & - \\
\hline & & 3. Medium & 15 & 45 \\
\hline & & 4. High & 18 & 55 \\
\hline & & 5. Very high & 0 & - \\
\hline \multirow{5}{*}{ D. } & \multirow{5}{*}{ Member participation } & 1. Very low & 0 & - \\
\hline & & 2. Low & 6 & 18 \\
\hline & & 3. Medium & 15 & 45 \\
\hline & & 4. High & 12 & 36 \\
\hline & & 5. Very high & 0 & - \\
\hline
\end{tabular}

Source : Main data (2019)

From the table above, it could be seen that the motivation and interest of the management are generally at the high criteria, which means that the management has interest, spirit and enthusiasm in running the organization, and willing to sacrifice in terms of time and others. The motivation of members is classified as moderate criteria, which means that members also have spirit and enthusiasm in managing the organization. The participation of the management, both core and supporter in general, in terms of holding meetings, is always active and complete, and members $(>50 \%)$ also participate.

Every organization certainly has rules that apply. In this case, evaluating the extent to which poktan / organizations know the rules and enforcement of the penalty that have been imposed. The percentage of institutional rules in Lembah Seulawah District can be seen in Table 3.

Table 3. Percentage of Institutional Rules in Lembah Seulawah Sub District, Aceh Besar District in 2019

\begin{tabular}{|c|c|c|c|c|}
\hline No & The Rules & Criteria & $\begin{array}{c}\text { Total } \\
\text { (people) }\end{array}$ & Percentation (\%) \\
\hline
\end{tabular}




\begin{tabular}{|c|c|c|c|c|}
\hline \multirow[t]{5}{*}{ A. } & \multirow[t]{5}{*}{ Institutional rules } & 1. Very low & 0 & - \\
\hline & & 2. Low & 0 & - \\
\hline & & 3. Medium & 8 & 24 \\
\hline & & 4. High & 25 & 76 \\
\hline & & 5. Very high & 0 & - \\
\hline \multirow[t]{5}{*}{ B. } & \multirow[t]{5}{*}{ Achievement of institutional rules } & 1. Very low & 0 & - \\
\hline & & 2. Low & 0 & - \\
\hline & & 3. Medium & 9 & 27 \\
\hline & & 4. High & 24 & 73 \\
\hline & & 5. Very high & 0 & - \\
\hline \multirow[t]{5}{*}{ C. } & \multirow[t]{5}{*}{ Enforcement of institutional rules } & 1. Very low & 0 & - \\
\hline & & 2. Low & 6 & 18 \\
\hline & & 3. Medium & 12 & 36 \\
\hline & & 4. High & 15 & 45 \\
\hline & & 5. Very high & 0 & - \\
\hline \multirow[t]{5}{*}{ D. } & \multirow[t]{5}{*}{ Internal pinalty enforcement } & 1. Very low & 0 & - \\
\hline & & 2. Low & 6 & 18 \\
\hline & & 3. Medium & 12 & 36 \\
\hline & & 4. High & 15 & 45 \\
\hline & & 5. Very high & 0 & - \\
\hline
\end{tabular}

Source : Main data (2019)

The evaluation result was found that each organization has a regulation in water management institutions, and most of the management and members know that "every process of opening and closing water when going down to the rice field is determined by deliberations". These rules are enforced in a disciplined and fair manner, so that there are no significant cases and there is no lead to enforcement of penalty.

After evaluating the internal management and members of institutional organizations, it is important to see the extent of the interactions that have been carried out with stakeholders in supporting the course and process of water management in Lembah Seulawah District. It can be seen in Table 4 .

Table 4. Percentage of Interactions with Water Management Institutional Stakeholders in Lembah Seulawah Sub District, Aceh Besar District in 2019

\begin{tabular}{|c|c|c|c|c|}
\hline No & Interaction with stakeholder & Criteria & $\begin{array}{c}\text { Total } \\
\text { (people) }\end{array}$ & Percentation (\%) \\
\hline \multirow[t]{5}{*}{ A. } & \multirow{5}{*}{ Support from outside parties } & 1. Very low & 0 & - \\
\hline & & 2. Low & 0 & - \\
\hline & & 3. Medium & 15 & 45 \\
\hline & & 4. High & 18 & 55 \\
\hline & & 5. Very high & 0 & - \\
\hline \multirow[t]{5}{*}{ B. } & \multirow{5}{*}{ The ability in using information } & 1. Very low & 0 & - \\
\hline & & 2. Low & 12 & 36 \\
\hline & & 3. Medium & 9 & 27 \\
\hline & & 4. High & 12 & 36 \\
\hline & & 5. Very high & 0 & - \\
\hline
\end{tabular}

Source : Main data (2019)

The stakeholder of water management institutions in Lembah Seulawah sub district part of Agricultural Extension Center (BPP), Field Extension (PPL), the Agricultural Service, and the Aceh Agricultural Technology Research Center (BPTP). The stakeholder role is carried out indirectly and informal, it means that if there are obstacles in the field, poktan can contact them anytime without being tied to a special agenda. Usually, special interactions are carried out 1-7 times in one growing season. The main sources of information are generally obtained 
from poktan, poktan members, BPP and Agricultural Service. The objectives of each stakeholder are generally to provide assistance in the form of production inputs, agricultural equipment and technology. Table 4. above, support from outside parties such as BPTP, Agricultural Service and Regional Government is considered highly, almost all parties provide assistance both financial, management and information technology innovation. However, the table show that it does not all organizations are able to absorb information on technological innovation and make it useful. Some organizations use outside information effectively and responsibly.

\subsection{The evaluation result of water management institutions}

The evaluation was carried out on farmer group regarding the institution whether to provide solutions to water management problems, institutional benefits and what suggestions could be given for the sustainability of the planting index improvement program in Lembah Seulawah sub district, Aceh Besar district.

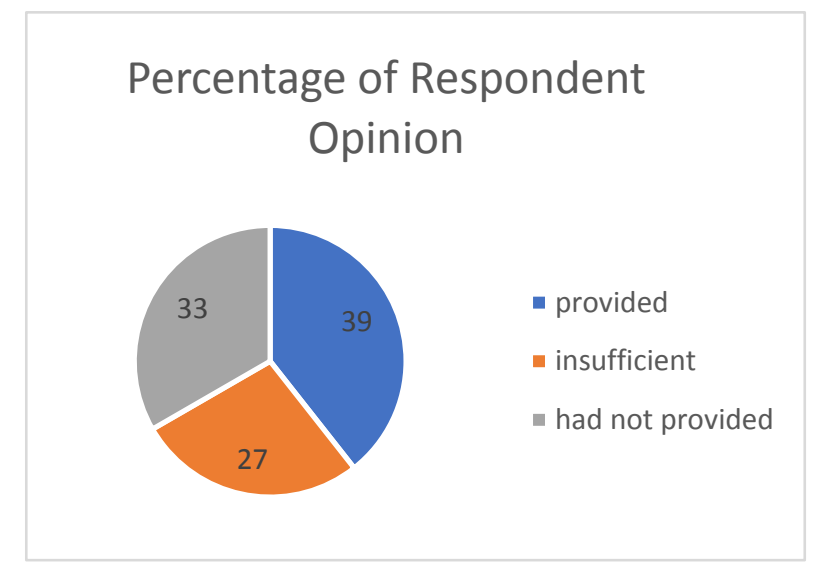

Fig 1. Percentage of Respondents' Opinions on Institutional of Water Management in Lembah Seulawah sub-district, Aceh Besar district 2019

The institutions were expected to provide the solutions to water management problems to increase the cropping index (IP). From the evaluation results, it was found that only $39 \%$ stated that the institution provided a solution to water problems in their area, while the rest stated that it was insufficient and it had not provided a solution in increasing IP. The benefits were the farmers can manage the adequacy of water in paddy fields / agricultural land in an orderly manner and according to crop needs.

\section{Conclusion and recommendation}

The empowerment of water management institutions in Lembah Seulawah sub district, Aceh Besar has four institutional assessments for farmer groups in increasing IP, namely: 1) general performance of the institution, the process of forming the organization is carried out on the basis of mutual consensus, at the end of each year an evaluation of the performance of the management is carried out, all targets are achieved and measurable, assets owned are complete and functioning well, the implementation of monev is openly conducted once a year, has a good relationship with the government by being involved in agricultural development at the regional/central level. The obstacles faced are low administrative order, 2) Motivation and internal institutional participation, the management has high motivation in running the organization and actively participates $(>50 \%)$ in holding meetings, 3$)$ The 
institutional rules, there is no enforcement of penalty because the rules are set by deliberation and enforced with discipline, 4) The interaction with stakeholders, carried out intensely 1-7 times in one planting season, the assistance provided is appropriate but some have not been able to utilize it. The evaluation was obtained from $39 \%$ of poktan stated that the institution had not provided a solution for increasing IP.

Acknowledgement. The author would like to thank all parties at the Aceh Agricultural Technology Research Center, who have involved and included me in the Activity of Increasing the Planting Index and giving me the opportunity to write scientific papers relating to these activities.

\section{References}

1. K.S. Indraningsih, D.K.S. Swastika, S. Susilowati, Syahyuti, A. Askin. Development of Farmers' Institutional Models and Agricultural Extension to Support the Implementation of Modern Agricultural Programs. Http://Pse.litbang.pertanian.go.id. (2018)

2. Hermanto, Swastika. Agricultural Policy Analysis. 9, 4 (2011)

3. Sapar. Journal of Accounting. 3, 1 (2017)

4. F. Lukman- Journal. Inference. 5, 1 (2017)

5. E.N. Fu'ad. Journal of Media Economics and Management. 30, 1 (2015)

6. A. Sugiarti, M.F. Ma'ruf. Journal of Publication. 4, 4 (2016)

7. D.A. Rizal, Journal of Community Empowerment: Media for Development Thought and Da'wah. 1, 2 (2017)

8. A. Octavia, I. Masriani, S. Rosita. Journal of Community Service. 30, 3 (2015)

9. N. Muin, W. Insan. Ebony Bulletin. 15, 1 (2018)

10. D. Diniyati. Indonesian Journal of Agroforestry. 1, 1 (2018)

11. S. Susanti. E-Journal of Public Administration. 3, 3 (2015)

12. Suyasdipura, I. L. Nyoman, M. Nada, I. K. Widnyana. Institute for Research and Community Empowerment (LPPM) Unmas Denpasar, Bali Province. (2016)

13. A.S. Perdana. Journal of Agricultural Sciences Tropics and Subtropics. 1, 1 (2016)

14. I. M. Suryana, T.J. Setiyono, C.S. Murdoyuwono. Bakti Saraswati Journal. 4, 2 (2015)

15. N. Tessar. Strengthen Economic Institutions of Farmers, Ministry of Agriculture to Build Modern Agriculture Corporations in Karawang. Online Coverage 6. (2018)

16. I.S. Ruhimat. Journal of Forestry Social and Economic Research. 14, 1 (2017)

17. H. Eskarya, Elihami. Non Formal Education Journal. 1, 1 (2020)

18. N. Sutrisno, A. Hamdani, H. Sosiawan. Water Resources Management Supports the Rice Planting Index. Repository.ut.ac.id. (2016)

19. Strategic Plan of the Ministry of Agriculture's Agricultural Research and Development Agency. 2015-2019. Revised Edition. Ministry of Agriculture R.I. (2016)

20. U. Maman, Journal of Agribusiness. 8, 2 (2014)

21. F. Arlius, Irsyad, D. Yanti. Journal of Rona Agricultural Engineering. 10, 1 (2017)

22. Handaka, A. Prabowo. Journal of Agricultural Policy Analysis. 11, 1 (2014)

23. Aceh's Central Statistics Agency (BPS). Data on Rice Production and Harvested Area. BPS Aceh Province. (2017)

24. N. Heryani, B. Kartiwa, A. Hamdani, B. Rahayu. Journal of Soil and Climate 41, 2 (2017)

25. BBP2TP Ministry of Agriculture. Guidelines for Implementing Activities for the Application of Technological Innovations to Improve the Planting Index, BBP2TP. Bogor. (2018)

26. Hermanto. Farmers Institutional Development. Opinion, Bangka Pos, January 16, (2010) 